\title{
Study of onion dehydration
}

A. P. Chaudhari*, Ku. Vrushali Jadhav and A. B. Kshetre

Department of Process and Food Engineering, Shiv Shankar College of Agricultural Engineering and Technology, Mirajgaon, Ahmednagar (M. S.) India

(Email: ashokpchaudhari2015@gmail.com)

\section{SUMMARY :}

Dehydration of onion is prime important processing operation. The matured white onions with uniform size were selected for experiment. Onion rings were used for dehydration. Effect of various temperatures $\left(60^{\circ} \mathrm{C}, 70^{\circ} \mathrm{C}\right.$ and $\left.80^{\circ} \mathrm{C}\right)$ on the onion rings were observed for moisture loss at 30 minute interval until the moisture content of the sample reached to $4 \%$ (wb). Various drying characteristics, dehydration ratio of onion rings were studied for desired temperatures. The onion rings dehydrated at $60^{\circ} \mathrm{C}$ temperature had more overall acceptability (6.54) as compared to others and onion rings rehydrated at $60^{\circ} \mathrm{C}$ temperature had maximum overall acceptability (5.87).

KEY WORDS : Onion, Dehydration, Drying characteristics, Sensory evaluation, Statistical analysis

How to cite this paper : Chaudhari, A.P., Jadhav, Ku. Vrushali and Kshetre, A.B. (2020). Study of onion dehydration. Internat. J. Proc. \& Post Harvest Technol., 11(1) : 7-11. DOI: 10. 15740/HAS/IJPPHT/11.1/711. Copyright@ 2020: Hind Agri-Horticultural Society. 